\title{
SISTEMAS PRODUTIVOS E POLÍTICAS PÚBLICAS EM ASSENTAMENTOS RURAIS DO ESTADO DE SÃO PAULO: SIMILITUDES E DIFERENÇAS ENTRE DUAS REGIÕES
}

\author{
PRODUCTIVE SYSTEMS AND PUBLIC POLICY IN RURAL SETTLEMENTS \\ OF SÃO PAULO: SIMILARITIES AND DIFFERENCES BETWEEN TWO \\ REGIONS
}

\section{SISTEMAS PRODUCTIVOS Y POLÍTICA PÚBLICA EN ASENTAMIENTOS RURALES DE SÃO PAULO: SIMILITUDES Y DIFERENCIAS ENTRE DOS REGIONES}

\author{
Vera Lúcia Silveira Botta Ferrante ${ }^{1}$ \\ Centro Universitário de Araraquara - UNIARA \\ mestrado@uniara.com.br \\ Henrique Carmona Duval ${ }^{2}$ \\ IFCH/UNICAMP \\ henriquecarmona@hotmail.com \\ César Giordano Gêmero ${ }^{3}$ \\ Centro Universitário de Araraquara - UNIARA \\ giordano_z@hotmail.com
}

\begin{abstract}
Resumo: O presente trabalho apresenta resultados de pesquisa junto aos assentamentos federais em duas macrorregiões do estado de São Paulo: região Central e região Leste. Priorizamos caracterizar os principais sistemas produtivos e formas de comercialização. Por outro lado, o artigo também faz um primeiro retrato dos sistemas agrícolas a partir do Programa de Aquisição de Alimentos como incentivador do desenvolvimento nos assentamentos. Mostramos que a diversificação tanto da produção agrícola como dos meios de escoamento é estratégica para as famílias assentadas. Outros aspectos destacados são os estágios produtivos e as fontes de financiamento. Os resultados apontam que os assentamentos melhoram muito as condições de acesso a alimentos das famílias assentadas. A pesquisa mostrou ainda que as famílias assentadas vão constituindo um mercado consumidor para sua produção e mesmo um mercado interno nos assentamentos e, com os recentes programas de compra do governo, as garantias de escoamento da produção são maiores, intensificando-se a relação assentamentos e municípios. Além disso, a garantia de comercialização via executivos municipais vem se constituindo mais relevante enquanto política pública do que os créditos e financiamentos.
\end{abstract}

Palavras-chaves: Assentamentos Rurais; Análise Regional; Sistemas Produtivos; Programas de Compra do Governo; Autoconsumo.

\footnotetext{
1 Socióloga. Pesquisadora CNPq. Coordenadora do PPG em Desenvolvimento Regional e Meio Ambiente, Centro Universitário de Araraquara - UNIARA. mestrado@uniara.com.br

${ }^{2}$ Sociólogo. Doutorando em Ciências Sociais, IFCH/UNICAMP. henriquecarmona@hotmail.com

3 Zootecnista. Mestrando em Desenvolvimento Regional e Meio Ambiente, UNIARA. giordano_z@hotmail.com
} 


\begin{abstract}
This paper presents results of research with federal settlements in two geographical regions of the state of São Paulo: the Central and Eastern region. We focus here characterize the main types of production systems and marketing, in which we highlight the part destined to family self-consumption and flow through institutional markets. We show that both diversification of agricultural production and commercialization are strategic for the families settled. Other points highlighted are the stages of production and sources of funding. This picture of the production systems makes it clear that the settlements contribute to that families have better access to food, from access to land. The survey also showed that the resettled families will constitute a consumer market for their production and even an internal market in the settlements, but with the recent purchase programs of the government guarantees of product flow are larger and, therefore, intensifies the regarding settlements and cities.
\end{abstract}

Key Words: Rural Settlements; Regional Analysis; Production Systems; Programs of Government Purchases; Production for Self-Consumption.

Resumen: En este trabajo se presentan los resultados de la investigación con los asentamientos federales en dos regiones geográficas del estado de São Paulo: la región central y oriental. Dar prioridad a caracterizar los principales sistemas de producción y formas de comercialización. Por otra parte, el artículo también se hace un primer retrato de los sistemas agrícolas del Programa de Adquisición de Alimentos de alentar el desarrollo de los asentamientos. Se demuestra que tanto la diversificación de la producción agrícola y los medios de eliminación es estratégico para las familias asentadas. Entre otros asuntos que son las etapas de la producción y de las fuentes de financiación. Los resultados indican que los asentamientos mejorar en gran medida las condiciones de acceso a la alimentación de las familias asentadas. La encuesta también mostró que las familias asentadas constituirá un mercado de consumo para su producción e incluso un mercado interior y en los asentamientos, con los programas de compra recientes de gobierno, garantías de flujo de producto son más altos, la intensificación de las relaciones y los asentamientos municipios. Además, el material de marketing a través de los ejecutivos municipales es cada vez más relevante como política pública que los créditos y financiamiento. Palabras clave: Asentamientos Rurales, Análisis Regional, sistemas de producción, compra de programas de gobierno; granja.

\title{
INTRODUÇÃO
}

Este artigo é fruto de um projeto realizado pela Uniara (Centro Universitário de Araraquara) e pelo INCRA/SP, no qual foram feitos diagnósticos regionais sobre as possibilidades de desenvolvimento dos assentamentos rurais no estado de São Paulo. Foi seguida a delimitação das regiões do Estado conforme o INCRA/SP (2010): Oeste A (Pontal do Paranapanema), Oeste B (Andradina/Promissão), Central (Ribeirão Preto/Araraquara/Bauru) e Leste (Vales do Ribeira e Paraíba e Eixo Anhanguera). O presente artigo trata especificamente das regiões Central e Leste, no intuito de 
caracterizar os sistemas produtivos das produções vegetais e animais mais encontradas nos lotes familiares. A pesquisa fundamentou-se na aplicação de questionários semiestruturados, além de entrevistas com coordenadores e técnicos da assistência técnica, com lideranças políticas dos movimentos sociais e com lideranças produtivas e das organizações de assentados.

Segundo o INCRA/SP (2010), existiam 110 assentamentos federais no Estado em 2010. Para fins de amostragem e para dar conta de diferentes tipos de assentamentos, tomamos como base diferenciações relativas ao ano de implementação, tipo de modalidade, número de famílias e área do lote. Foram selecionados 43 assentamentos (dentre os quais alguns estaduais na região do Pontal do Paranapanema) que contemplassem os critérios iniciais, correspondendo a $39 \%$ do total de assentamentos federais e das 9.479 famílias destes projetos. Portanto, foram investigadas $55,41 \%$ das famílias assentadas nestas unidades administrativas selecionadas do INCRA do Estado de São Paulo, ou seja, 5.252 famílias residentes nestes 43 assentamentos ${ }^{4}$.

Procuraremos destacar os sistemas produtivos dos quatro principais grupos de cultivos vegetais encontrados (horticultura, cereais, fruticultura e tubérculos) e das três principais criações animais (gado leiteiro, aves e suínos), considerados isoladamente, de forma que os elementos que norteiam as comparações são: o estágio produtivo, destinação da produção, formas de comercialização e a existência de financiamento. Tais elementos estão sendo considerados para uma discussão do estágio de desenvolvimento dos assentamentos. No entanto, há outros elementos igualmente importantes a serem explorados na continuidade dos estudos, como os fatores ambientais, ecológicos e a divisão sexual do trabalho para a discussão dos sistemas agrícolas nos assentamentos rurais ${ }^{5}$.

\section{CONTEXTUALIZAÇÃO TEÓRICA}

As reflexões contidas neste artigo fazem parte de um ciclo de pesquisas voltado à relação assentamentos rurais e desenvolvimento em São Paulo, vista pela ótica de uma

\footnotetext{
${ }^{4}$ É importante destacar que se fizermos uma análise do total de famílias residentes em PA's ou PDS's do Estado, verificaremos que esta porcentagem cai para cerca de $30 \%$, já que o número total de famílias em assentamentos federais e estaduais, em 2010, era de 15.703.

${ }^{5} \mathrm{O}$ debate sobre acesso à água no sistema produtivo deverá ser explorado na continuidade das investigações, bem como a questão da divisão sexual do trabalho e do tipo de manejo (usos e custos de insumos internos e externos), dentre outros. No entanto, não pudemos incluir essa discussão no presente artigo pelo tamanho e proporção que tomaria.
} 
trama de tensões formada entre os agentes sociais que disputam e definem os rumos dessas experiências de reforma agrária nos distintos espaços de deliberação. Tais espaços, sobretudo políticos e estruturantes da vida das pessoas no interior dos assentamentos, guardam sempre uma margem para a livre deliberação de cada família assentada acerca do que e como produzir, no que empregar sua força de trabalho, com quem se associar, enfim, quais decisões tomar em diferentes momentos no fazer-se das famílias nos assentamentos.

A noção de uma trama de tensões, utilizada como instrumento analítico de compreensão da realidade, tem se mostrado útil na reconstituição de aspectos críticos da realidade dos assentamentos (FERRANTE, 2010). Os assentamentos são experiências inovadoras na gestão econômica do território, mas expressam tensões que são reveladoras das contradições e possibilidades da chamada agricultura familiar frente ao poder do capital agropecuário e agroindustrial, no âmbito do desenvolvimento social no campo paulista. A partir da noção de trama de tensões, essa pesquisa privilegia as relações travadas entre distintos agentes sociais, sendo destacados, as próprias famílias assentadas e os diferentes mediadores, tanto das políticas públicas como das possíveis alternativas produtivas, econômicas e políticas. O confronto desses atores é gerador da trama de tensões, opondo interesses e racionalidades diversas - mediante distintos projetos, compromissos e estratégias familiares ${ }^{6}$.

Por outro lado, temos trabalhado com o estudo dos modos de vida (re)elaborados pelas famílias assentadas (FERRANTE, 1994). Essa abordagem privilegiou os espaços da sociabilidade no interior dos assentamentos, as estratégias de produção e reprodução social das famílias e as mediações políticas constituídas entre essa busca por permanecer na terra e a atuação de órgãos e agências (estatais ou não) no tocante à elaboração de projetos de desenvolvimento nos assentamentos.

Para a discussão acerca do desenvolvimento nos assentamentos, partimos da concepção de Amartya Sen (2000), para quem o desenvolvimento é a expansão das liberdades individuais. No caso dessa investigação, isto se reflete na possibilidade dos assentados terem as rédeas de suas iniciativas em suas mãos, o que é contrariado, por exemplo, pelos constrangimentos impostos através das parcerias com setores

\footnotetext{
${ }^{6}$ Outro conceito que aparece imbricado ao de trama de tensões é o de campo, conforme o concebeu Pierre Bourdieu (1989), espaço social especializado no qual se defrontam agentes sociais que travam relações de força em busca do poder, ou da hegemonia sobre um capital específico. Neste espaço estão em disputa tanto os possíveis e distintos projetos de desenvolvimento dos assentamentos rurais, quanto a hegemonia política no território local/microrregional, ela mesma bastante definidora dos referidos projetos de desenvolvimento.
} 
agroindustriais e pela política de assistência técnica, pelos controles e medidas restritivas da autonomia dos assentados. Trata-se de uma abordagem relacional de assentamentos e desenvolvimento não ditada por uma lógica externa, nem indicativa de uma subordinação a um sistema de controles e de poderes (FERRANTE, 2010). Dentro dessa perspectiva, a terra não é, para as famílias assentadas, apenas ponto de partida para a produção de valores de troca, mas também para a garantia da segurança alimentar e do respeito às suas singularidades, ao fato de serem portadores de saberes, de iniciativas de cooperação que podem implicar em uma resignificação daquilo que lhes é imposto pelos mediadores internos e externos, dentro da lógica de monetarização da produção.

Portanto, a noção de trama de tensões implica analisar o desenvolvimento na trajetória dessas experiências de reforma agrária, frente aos constrangimentos estruturais que a sociedade lhes impõe, sobretudo através do mercado e do Estado, como também frente à necessária reelaboração da própria trajetória pessoal e familiar desses agricultores.

Como focos principais de análise dessas relações, na pesquisa, temos acompanhado a integração dos assentados às agroindústrias dos complexos canavieiro e granjeiro na microrregião de Araraquara e com laticínios para a produção de leite na região do Pontal do Paranapanema. A assimetria de informações nas relações entre assentados e agroindústrias nos contratos de "parceria", sobretudo para o plantio de cana de açúcar, marca a integração agroindustrial nos assentamentos (FERRANTE, BARONE, 2011).

Notadamente, existem outras possibilidades para o desenvolvimento das famílias. Conforme procuraremos demonstrar em dados, existe uma produção diversificada de alimentos nos assentamentos, que historicamente é voltada prioritariamente ao autoconsumo familiar, mas cujo excedente se reverte em renda para as famílias pela venda ocasional, por atravessadores, em feiras ou no mercado de varejo, além de se inserir em situações de trocas e doações dentre as famílias assentadas, alimentando suas redes de sociabilidade (DUVAL, 2009). Basicamente esses são os dois principais caminhos para o desenvolvimento das famílias assentadas por meio de atividades agrícolas.

Sem se esquecer das problemáticas relações com as agroindústrias, trazemos no presente artigo uma série de dados sobre os sistemas produtivos nos lotes das famílias 
assentadas em duas macrorregiões do estado de São Paulo, dados estes que expõem quais são os cultivos e criações prevalecentes na transformação do desenho agrícola dos lotes nos assentamentos e que trazem possibilidades e perspectivas ao desenvolvimento das famílias para além da integração agroindustrial.

\section{CARACTERIZAÇÃO DO UNIVERSO EMPÍRICO}

\section{Região Central}

A região Central do estado caracteriza-se pelo alto dinamismo do agronegócio com empresas sucroalcooleiras e madeireiras. Como cobre uma vasta extensão territorial, subdividimos a região em microrregiões, conforme o quadro de amostragem dos assentamentos investigados, a seguir:

Quadro 1 - Subdivisão da região Central.

\begin{tabular}{|l|l|l|l|l|l|}
\hline Região $^{7}$ & Município & Assentamento & Criação & $\begin{array}{l}\text { Número de } \\
\text { famílias }\end{array}$ & $\begin{array}{l}\text { Tamanho } \\
\text { médio do lote }\end{array}$ \\
\hline Norte & Colômbia & PA Formiga & $10 / 11 / 98$ & 58 & 14,5 ha \\
\hline \multirow{2}{*}{ Sul } & Iaras & PA Zumbi dos Palmares & $16 / 09 / 98$ & 332 & 16 ha \\
\cline { 2 - 6 } & Piratininga & PA Santo Antonio & $19 / 12 / 01$ & 26 & 19 ha \\
\hline $\begin{array}{l}\text { Centro } \\
\text { A }\end{array}$ & São Carlos & $\begin{array}{l}\text { PA Comunidade Agrária } \\
\text { Nova São Carlos }\end{array}$ & $20 / 06 / 07$ & 110 & 7,5 ha \\
\cline { 2 - 6 } & Araraquara & $\begin{array}{l}\text { PA Bela Vista do } \\
\text { Chibarro }\end{array}$ & $27 / 05 / 89$ & 203 & 16 ha \\
\cline { 2 - 6 } & Descalvado & $\begin{array}{l}\text { PDS Comunidade } \\
\text { Agrária 21de Dezembro }\end{array}$ & $10 / 12 / 05$ & 40 & 5 ha \\
\hline $\begin{array}{l}\text { Centro } \\
\text { B }\end{array}$ & $\begin{array}{l}\text { Ribeirão } \\
\text { Preto }\end{array}$ & PDS Fazenda da Barra & $21 / 08 / 09$ & 440 & 1,5 ha \\
\hline
\end{tabular}

Fonte: Elaboração dos autores.

As microrregiões de Ribeirão Preto e Araraquara, por exemplo, são tratadas como a Califórnia Brasileira. Contrastando com este tônus de riqueza, a região apresenta um histórico de exploração e precarização dos trabalhadores e do uso da terra.

A característica de luta pela Reforma Agrária nesta região se estabelece a partir do contraponto do agronegócio com a possibilidade dos assentamentos, protagonizada pelos trabalhadores rurais que ora se vinculam ao movimento sindicalista (em especial a FERAESP), ora se ligam aos movimentos sociais (em especial o MST). É possível identificar territorialmente a disputa por estas instituições pelo maior rebanho nos assentamentos.

No caso específico das cidades mais próximas geograficamente à Araraquara, onde se encontra a sede do sindicato a força do mesmo se torna maior que a do MST,

\footnotetext{
${ }^{7}$ Esta subdivisão tem carácter meramente ilustrativa, em função de estarnos tratando de uma macrorregião que corta o Estado de norte a sul.
} 
neste caso específico, são os assentamentos de Araraquara, São Carlos e Descalvado. Já nas cidades de Ribeirão Preto, Iaras e Piratininga o MST (e outros movimentos com atuação mais discreta e localizada) têm uma atuação mais intensa. Da nossa amostragem, apenas a microrregião de Colômbia se caracteriza pela pouca atuação tanto da FERAESP como do MST, tendo como histórico de luta a ação do INCRA e prefeitura local. Em termos de organização política, no assentamento de Ribeirão Preto encontramos uma realidade bem particular, uma vez que embora a luta pela terra tenha sido organizada pelo MST, houveram rupturas que hoje subdividem o assentamento em quatro núcleos de movimentos sociais diferentes: o do Índio Galdino, do MST, do MLST e Bandeira Branca (ou Luiza Mahin).

Na microrregião de Araraquara, apesar da existência de diversificação agrícola que será apresentada posteriormente, é importante destacar a complexa relação de parceria agroindustrial, principalmente para plantio de cana-de-açúcar. Em outros estudos temos demonstrado a assimetria nas relações e nas informações, geradas entre "parceiros" tão distantes social e economicamente (FERRANTE, BARONE, 2011). Os benefícios da parceria têm se dado numa esfera estritamente econômica, embora seja difícil dimensionar tais benefícios quando levamos em conta os custos produtivos e os problemas ambientais (como contaminações e queimadas). Simbolicamente, temos discutido que os pacotes agrícolas exigidos pelas agroindústrias canavieiras para satisfazer suas necessidades produtivas acabam representando as amarras a que ficam submetidos os assentados, pois retiram-lhes autonomia em todo o processo produtivo e de comercialização, gerando inclusive o endividamento em muitos casos. Apesar disso, estimamos que $80 \%$ das famílias em assentamentos da microrregião de Araraquara $^{8}$ aderiram ao plantio de cana agroindustrial em 2010, segundo elas, pela falta de outras alternativas na história dos assentamentos ${ }^{9}$.

As principais alternativas ao desenvolvimento das famílias além da integração agroindustrial vêm se dando a partir da possibilidade de comercialização em programas de compra governamentais e em feiras de produtores municipais.

No assentamento em São Carlos, essa estratégia de comercialização também predomina, embora com maiores dificuldades pela falta de água e a quantidade de tocos

\footnotetext{
${ }^{8}$ Além do assentamento Bela Vista do Chibarro, há em Araraquara os assentamentos Monte Alegre e Horto Bueno de Andrada, que totalizam 600 famílias.

9 Vale mencionar que após longo período de pressão das organizações das famílias assentadas, o INCRA/SP acaba de autorizar o plantio de cana em parceria com agroindústrias em até $40 \%$ de cada lote.
} 
de eucaliptos da antiga fazenda que impedem o uso do solo, justamente porque durante a implementação do assentamento, a destoca não foi realizada.

Nos assentamentos de modalidade PDS essa forma de comercialização também predomina, principalmente os produtos de horticultura e fruticultura. Embora exista muita criação de pequeno porte (aves e suínos) esses produtos voltam-se mais ao autoconsumo do que para comercialização. Uma das principais dificuldades dos PDS's é o tamanho do lote. No PDS da Barra, em Ribeirão Preto, cada família possui um lote de aproximadamente 1,5 hectare. Apesar do tamanho do lote de cada família ser bem menor em relação aos outros assentamentos, os técnicos do INCRA informam que existem áreas (de APP e mata ciliar) nas quais os assentados podem fazer uso coletivo, porém na prática existem poucos projetos para uso dessas áreas.

É necessário destacar que os PDS's se diferenciam dos PA's sobretudo em função do TAC (Termo de Ajustamento de Conduta). Os PDS's estabelecem normas para o uso do solo e demais recursos naturais, bem como regulam o uso de insumos externos e poluentes, como os agrotóxicos, no assentamento. Neste sentido, as normas do TAC podem funcionar para a prática de uma agricultura ecológica, mas também podem ser medidas restritivas das estratégias dos assentados e, sobretudo, dos problemas por eles enfrentados nas lavouras. A pesquisa não identificou como contrapartida ao modelo, por exemplo, orientações técnicas e créditos diferenciados. $\mathrm{O}$ modelo PDS foi pensado e executado primeiramente na região Amazônica, no intuito de compatibilizar os assentamentos rurais com a preservação da biodiversidade. Transposto para o estado de São Paulo, certamente não encontrou o mesmo cenário de preservação do bioma da região, no entanto, prevê várias ações visando a recuperação da vegetação nativa, como projetos em parceria com universidades e centros de pesquisa, como a Embrapa Meio Ambiente (Jaguariúna).

A microrregião na qual está inserido o assentamento de Colômbia é igualmente influenciada pelo complexo canavieiro e os assentados possuem contratos de fornecimento com as usinas. Por outro lado, o assentamento já passou por projetos de produção de grãos, como a soja e criação de gado leiteiro financiados pelo PRONAF. No entanto, os assentados mencionam que foi justamente a parceria para plantio de cana que possibilitou uma maior capitalização das famílias. Assim como relatado no assentamento Bela Vista do Chibarro, o dinheiro recebido com a cana vem sendo investido na produção de outras coisas, no caso, para a produção de abacaxi. 
Na microrregião de Piratininga e Iaras, os assentamentos são fortemente influenciados pelo complexo papeleiro em seu entorno. Em Iaras, apesar de haver muitos produtores de gado leiteiro e uma produção mais diversificada para o autoconsumo, cujo excedente tem sido comercializado no mercado institucional, há forte presença de eucaliptos nos lotes. Trata-se de um assentamento em constante transformação, já que integra uma grande área pública largamente utilizada pelo complexo papeleiro e que vem sendo objeto de novas ocupações de terras, de forma que há núcleos de assentamento mais antigos e mais novos. À época da nossa pesquisa de campo, em 2011, havia nova área sendo ocupada pelo MST.

Relatos de praticamente todos os assentados entrevistados mostram um desanimo com a situação. No inicio, a Cooperativa de Comercialização e Prestação de Serviços dos Assentados de Reforma Agrária de Iaras e Região (COCAFI), em parceria com o INCRA, prometeram extrair a madeira e reverter o dinheiro para o assentamento. Projetos grandes - como a construção de um laticínio no valor de $\mathrm{R} \$ 425.000,00$ - foram discutidos e anunciados em assembleias com os assentados, porém eles relataram que apenas viram caminhões carregados de madeira saindo do assentamento e nenhuma benfeitoria de grande porte foi realizada. Os assentados reclamaram que o dinheiro da madeira foi revertido apenas em 2 tanques de resfriamento de leite, 10 ordenhadeiras mecânicas, 100 kit’s horta e 2 tratores para a cooperativa, mas isso estava muito aquém do que havia sido prometido e acordado.

O PA Santo Antonio está igualmente inserido em um entorno completamente envolvido por grandes monoculturas de eucaliptos e também fazendas de bovinocultura. Porém, a pesquisa não identificou uma relação tão problemática e nem a presença tão forte de eucaliptos no assentamento. Foi verificada grande produtividade de mandioca, pelo fato de existirem farinheiras na região, especialmente na cidade de Itapeva, com as quais há possibilidade de comercialização. Por outro lado, há também muitos produtores de cereais (sobretudo feijão e milho). Um dos técnicos que presta assistência na região mencionou o potencial da região para a fruticultura.

\section{Região Leste}

A região Leste, delimitada pelo INCRA-SP, destaca-se pela vasta extensão territorial e pela heterogeneidade dos assentamentos. Por isso, subdividimos a região em três, conforme quadro a seguir, no qual apresentamos os assentamentos que fizeram 
parte da amostragem da pesquisa. Os assentamentos dessa região também são diferenciados quanto à data de criação, modalidade, número de famílias e o tamanho médio dos lotes ${ }^{10}$.

Quadro 2 - Subdivisão da região Leste.

\begin{tabular}{|l|l|l|l|l|l|}
\hline Região & Município & Assentamento & Criação & $\begin{array}{l}\text { Número de } \\
\text { famílias }\end{array}$ & $\begin{array}{l}\text { Tamanho } \\
\text { médio do } \\
\text { lote }\end{array}$ \\
\hline $\begin{array}{l}\text { Vale do } \\
\text { Ribeira }\end{array}$ & Apiaí & $\begin{array}{l}\text { PDS Luis de } \\
\text { Macedo }\end{array}$ & $27 / 07 / 06$ & 86 & 6 há \\
\cline { 2 - 6 } & Itapetininga & $\begin{array}{l}\text { PA Vinte e Três de } \\
\text { maio }\end{array}$ & $04 / 12 / 07$ & 46 & 7 há \\
\hline $\begin{array}{l}\text { Vale do } \\
\text { Paraíba }\end{array}$ & $\begin{array}{l}\text { Biritiba } \\
\text { Mirim }\end{array}$ & $\begin{array}{l}\text { PA Sítio Casa } \\
\text { Grande }\end{array}$ & $19 / 12 / 06$ & 48 & 4,5 há \\
\cline { 2 - 6 } & $\begin{array}{l}\text { São José dos } \\
\text { Campos }\end{array}$ & $\begin{array}{l}\text { PA Nova Esperança } \\
\text { I }\end{array}$ & $05 / 11 / 01$ & 63 & 5 há \\
\cline { 2 - 6 } & $\begin{array}{l}\text { Tremembé } \\
\text { PA Fazenda }\end{array}$ & $\begin{array}{l}24 / 04 / 95 \\
\text { Conquista }\end{array}$ & 97 & 9 há \\
\hline $\begin{array}{l}\text { Eixo } \\
\text { Anhanguera }\end{array}$ & Americana & $\begin{array}{l}\text { PDS Comuna da } \\
\text { Terra Milton Santos }\end{array}$ & $11 / 07 / 06$ & 85 & 2 há \\
\cline { 2 - 6 } & Cajamar & PDS São Luiz & $27 / 07 / 06$ & 37 & 0,5 há \\
\hline
\end{tabular}

Fonte: Elaboração dos autores.

Segundo os técnicos entrevistados, o processo de seleção das famílias é amparado legalmente pelas normas específicas do INCRA. A prioridade de assentamento das famílias acampadas para solução de conflitos locais foi levada em conta em todos os casos. Houve participação do MST e das famílias acampadas organizadas.

Também segundo os técnicos, o planejamento dos assentamentos e ocupação das áreas após a seleção das famílias contou com a participação das famílias e do MST junto com o INCRA. Por outro lado, vale destacar que há dois tipos de assentamentos na região: o PA e o PDS, cujas principais diferenças situam-se nos Termos de Ajuste de Conduta (TAC) assinados pelos assentados em um e outro caso.

Na região do Vale do Ribeira, há uma tendência para a expansão das fazendas com monoculturas de pinus e/ou eucalipto e o avanço do agronegócio de papel e celulose. Principalmente em Itapetininga, existem vastas extensões de terra com essas monoculturas e em todo entorno dos lotes do assentamento visitado. Antes do assentamento 23 de Maio e outros no município serem decretados, as áreas eram ocupadas por pasto e eucalipto (como por exemplo, no assentamento Carlos Lamarca).

\footnotetext{
${ }^{10} \mathrm{O}$ tamanho do lote refere-se a uma média, pois há assentamentos com grande diferença, por exemplo o de Apiaí, que tem lotes que vão de 3,5 ha, outros com 6 ou 7 ha e outros ainda com 10 ha.
} 
A origem das famílias, em sua maioria filhos de assentados no município vizinho de Itapeva, talvez explique a semelhança no que diz respeito à ocupação e produção.

Já o assentamento de Apiaí, embora inserido numa região com tal influência da estrutura fundiária, localiza-se numa zona de amortecimento entre dois Parques de Preservação (Parque Estadual Intervales e Parque Estadual Turístico do Alto Ribeira PETAR). Segundo os assentados, quando da ocupação da terra pelo assentamento, a fazenda estava degradada. Antes do assentamento, a fazenda era explorada por madeireiros que retiravam cedro e outras madeiras de lei. Com a falência da madeireira, a fazenda passou para o Banco Sudameris. Este vendeu as terras para uma mineradora, que criava 1.500 cabeças de búfalos. Só depois do assentamento, a mata atlântica foi se regenerando, o que lhe dá um grande potencial turístico ecológico. A região também é forte no cultivo de tomate (atividade agrícola que garante renda aos pequenos produtores locais). Mas como se trata de um cultivo muito intensivo em insumos químicos, não compatibiliza com as práticas agrícolas normalmente adotadas pelos assentados, especialmente no assentamento de Apiaí que é PDS (Projeto de Desenvolvimento Sustentável) e possui normas específicas de exploração agrícola que impedem o uso de agrotóxicos.

As famílias assentadas no PA 23 de Maio (Itapetininga) são oriundas, em sua maioria, dos assentamentos de Itapeva, eram agregados que com o aumento das famílias de origem se mobilizaram junto com o MST para a conquista de outra área.

A área do PA Ipanema (Iperó) decretada em 1995 foi ocupada por cerca de 700 famílias, quase 3.000 pessoas, em maio de 1992, época em que foi criada a Floresta Nacional de Ipanema (hoje sob gerência do ICM/Bio). A relação conflituosa com a administração da Floresta Nacional, verificada desde o início da criação do assentamento, que ocorreu devido à ocupação deste grande número de famílias, foi amenizada após assinatura do Acordo de Cooperação Técnica entre os órgãos INCRA e ICM/Bio, acompanhado pela AGU, no ano de 2010. Este acordo visa a transição agroecológica da produção neste assentamento para solução da questão fundiária na área, visto que o PA está situado na zona de amortecimento da unidade.

O PA Carlos Lamarca (Itapetininga), decretado em 1999, também é fruto da mesma mobilização por reforma agrária ocorrida na região metropolitana de Sorocaba nos anos 90. Estas famílias ficaram acampadas em vários municípios da região até a criação do assentamento. 
Na região do Vale do Paraíba predomina produção de hortas para abastecimento da capital e do ABC. Principalmente mais perto desses centros urbanos (Biritiba Mirim), onde no caminho para o assentamento pudemos ver inúmeras hortas grandes, algumas voltadas ao mercado de orgânicos (pequenos e médios produtores inseridos nas grandes redes de varejo, como o supermercado Pão de Açúcar).

Para a prefeitura de São José dos Campos, a área em que o assentamento está inserida é considerada macrozona de expansão urbana (Zona de Chácaras de Recreio, ZCHR). Na entrada do assentamento e fazendo divisa com os primeiros lotes existe um condomínio (Colinas do Parahyba), de casas de luxo, o muro que cerca toda sua extensão está pronto e algumas casas já estão construídas. Seus donos são geralmente pessoas da cidade de São José dos Campos que moram em prédios no centro e estão construindo mansões no condomínio afastado da cidade para passaram os finais de semana. $\mathrm{O}$ asfalto vai até a portaria do condomínio, depois começa o assentamento e a estrada de terra.

Por outro lado, a região também é marcada pela presença de fazendas produtoras de gado de corte com grande aporte tecnológico e que participam de programas de melhoramento genético (PAINT), focado principalmente o melhoramento genético de animais alimentados a base de pasto.

Por fim, no que denominamos eixo Anhanguera predomina o eucalipto e as indústrias de papel e celulose em Cajamar e, em Americana, predomina a cana e um parque industrial mais diversificado.

Após um panorama geral sobre esta região, abrangendo também aspectos do assentamento de Limeira, como exemplificação da luta pela terra e dos desdobramentos deste complexo processo, vamos nos deter um pouco no aprofundamento da situação do assentamento de Cajamar.

Os Projetos de Desenvolvimento Sustentável São Luiz (Cajamar), Milton Santos (Americana) e Elizabeth Teixeira (Limeira) são frutos da luta do MST travada nos anos 2000, momento em que agrupa-se, com bastante ênfase, à bandeira da reforma agrária a questão ambiental e a recuperação das terras públicas. Esses assentamentos possuem muitas semelhanças, entre elas a proximidade dos grandes centros urbanos. As áreas eram ocupadas por pasto e eucalipto (São Luiz e Elizabeth Teixeira) e cana e soja (Milton Santos). O PDS São Luiz foi objeto de compra através do Decreto 433/92, o Milton Santos pertencia ao INSS e foi cedido ao INCRA para solucionar conflito na 
região e o Elizabeth Teixeira, área da União, ainda é objeto de disputa judicial entre a União/INCRA e a prefeitura do município de Limeira.

A origem das famílias desses assentamentos é essencialmente urbana. O trabalho de base do MST foi realizado nos municípios de São Paulo, Campinas e entorno em épocas distintas. Dessa forma, a maioria dos beneficiários realizou e ainda realiza, esporadicamente, trabalhos relacionados à construção civil, doméstica, dentre outras atividades nos municípios vizinhos.

O PDS Milton Santos (Americana) foi criado em 2006, após sucessivos despejos na grande Campinas, região caracterizada pela forte especulação imobiliária, em dezembro de 2005, as famílias foram para área com autorização do INCRA. As famílias do PDS São Luiz também foram assentadas no ano de 2006 e também após diversos despejos na região metropolitana de São Paulo. A área da fazenda foi adquirida pelo INCRA através do Decreto 433/92.

O Horto Florestal Tatu, no município de Limeira, ainda é objeto de disputa judicial. A criação do assentamento está suspensa por conta do Mandado de Segurança impetrado pela prefeitura do município no STJ. As famílias já passaram pelo processo de seleção e encontram-se numa área limitada pela justiça federal de Piracicaba (de 100 ha) dentro do horto, aguardando solução litigiosa.

Os PDS Milton Santos e São Luiz possuem áreas reduzidas. No momento de criação destes assentamentos, o modelo PDS foi adotado em concordância com as reivindicações e denúncias (ambientais) das famílias organizadas, sendo também, semelhante ao projeto "Comuna da Terra" do MST. No decorrer da permanência das famílias, a disposição coletiva foi alterada, os beneficiários resolveram dividir as parcelas individualmente, ou seja, cada família ficou com seu lote de 1 ha, aproximadamente. Ainda existem áreas de produção coletiva nos dois assentamentos, porém a equipe relatou dificuldade em dimensionar este trabalho em grupo.

\section{UM RETRATO DOS SISTEMAS PRODUTIVOS}

Com relação à produção agrícola vegetal, podemos traçar um paralelo entre as duas regiões e concluir que são quatro categorias de cultivos mais presentes nos assentamentos: a horticultura, o cultivo de cereais, a fruticultura e o cultivo de mandioca e outros tubérculos. 
Na região Leste a horticultura predomina sobre as demais culturas produzidas, com $35 \%$ de toda a produção vegetal da região. Em seguida, vem a fruticultura (29\%), o cultivo de mandioca e outros tubérculos $(20 \%)$ e o cultivo de cereais $(16 \%)$, como o arroz, o feijão, o milho e a soja.

Já na região Central a situação é um pouco diferente, pois os mesmos quatro grupos de cultivos aparecem mais equilibrados. A fruticultura aparece com $21 \%$ de toda produção vegetal. Em seguida aparecem o cultivo de cereais e a horticultura, cada um representando $20 \%$. O cultivo da mandioca e outras tuberosas são responsáveis por $18 \%$ do que é cultivado em termos de produção vegetal. Podemos citar ainda, com menor destaque, o cultivo de cana-de-açúcar e de eucalipto (ambos com 5\%), lembrando que nessa região existem assentados que possuem contratos com grandes agroindústrias para o fornecimento principalmente de cana, como nos assentamentos de Araraquara e de Colômbia. Essa informação geralmente é omitida porque a prática não era legalizada pelo INCRA até pouco tempo.

\section{Cereais: a prioridade do autoconsumo}

Explorando a questão do cultivo de cereais na região Leste, dos assentados que trabalham com este tipo de cultura, $75 \%$ das lavouras encontram-se produtivas e 13\% em produção e implementação, ou seja, possivelmente existe um número significativo de assentados que estão ampliando a área. Nesta região, a produção de cereais se concentra nos municípios de Itapetininga e Apiaí. Itapeva é outra localidade na qual os assentados produzem muitos grãos, pois além das boas condições, muitas pessoas desses assentamentos são provenientes do estado do Paraná e tinham experiência em plantar grãos. Na região Central, dos que produzem cereais, $82 \%$ estão em estágio produtivo, enquanto que $3 \%$ estão em fase de implementação e $15 \%$ em produção e implementação.

Com relação à destinação da produção, as duas regiões possuem como característica principal o autoconsumo dos cereais. Na região Central, $41 \%$ da produção é destinada para o autoconsumo, 22\% para vendas diretas, somente $8 \%$ por meio de atravessadores. Outros $8 \%$ destinam-se para a Merenda e 14\% para o PAA, totalizando $22 \%$ destinados aos mercados institucionais. Outros $2 \%$ são comercializados em feiras, $2 \%$ por outras formas de comercialização e $3 \%$ em forma de troca com outros assentados e não computados de forma monetária. 
Já na região Leste a maioria (44\%) dos assentados que produzem cereais, o fazem prioritariamente para consumo próprio, 31\% vendem para o PAA, 19\% vendem de forma direta e $6 \%$ vendem em feiras. Este dado realça a importância do estímulo para a produção de cereais e grãos em geral nas duas regiões, pois a maior parte da produção é destinada ao consumo pelos próprios assentados, embora o mercado institucional venha ganhando uma importância em termos de comercialização que antes era partilhada entre atravessadores, feiras e outras vendas diretas.

Observando os dados referentes ao financiamento do cultivo de cereais nas duas regiões é possível constatar a baixa porcentagem de assentados que obtiveram crédito para este tipo de cultura. $\mathrm{Na}$ região Leste, apenas $12 \%$ das lavouras de cereais implantadas foram financiadas, contra $75 \%$ que não tiveram nenhum tipo de financiamento. Da pequena parcela de financiamentos realizados para cereais, notamos que estão empatados em 12\% feitos pelo PRONAF e INCRA, contra 63\% realizados com outros, sejam estas instituições financeiras bancárias, associações/cooperativas, dentre outras.

Na região Central apenas $23 \%$ dos produtores receberam financiamento, contra $77 \%$ das lavouras implantadas sem financiamento. Com relação ao financiamento nesta região, prepondera o Pronaf com 50\%. Os demais estão bem próximos entre si: $16 \%$ pelo INCRA, 17\% pelo banco e $17 \%$ por outros. Isso mostra a importância que há em saber produzir e armazenar as próprias sementes, uma prática comum dentre os assentados que cultivam principalmente milho e feijão.

\section{Horticultura: o carro chefe do sistema produtivo}

De todas as culturas trabalhadas dentro dos assentamentos das duas regiões, a horticultura é a que merece maior destaque, responsável pela maior porcentagem da região Leste e segunda maior da região Central. Destaca-se por absorver grande volume de mão de obra familiar e pela inserção nos programas de compra do governo. Com relação ao estágio produtivo da região Leste é possível afirmar que, dos assentados que trabalham com a horticultura, 62\% das hortas estão produtivas, 13\% em processo de implementação e $25 \%$ estão produzindo e em processo de ampliação. Na região Central, as hortas produtivas representam $84 \%$, outros $5 \%$ estão implementando e $7 \%$ no estágio produtivo e de implementação. Há que se referir que esta prática de produzir e ampliar a horta ou outro sistema produtivo, pode se confundir com as práticas de rotação de 
culturas e adubação verde, práticas comuns nos assentamentos visitados. Esta situação é parecida com o cultivo de cereais da mesma região.

Os dados sobre o destino da produção da horticultura na região Leste mostram a diversidade de formas de comercialização praticada pelos assentados. É possível perceber a extrema importância do cultivo para subsistência, sendo que $35 \%$ da produção é destinada para autoconsumo, outros 35\% comercializam via PAA, 11\% em vendas diretas, $8 \%$ para a merenda escolar, $6 \%$ em feiras e somente $5 \%$ com atravessadores. Esta diversidade traz um potencial competitivo na hora da venda da produção, muito bom para que o produtor obtenha preços mais elevados e, principalmente, para que não seja explorado por atravessadores. Com isto, os produtores estão conseguindo preços justos durante todo o ano.

Podemos traçar um paralelo com a região Central e destacar a grande importância do autoconsumo e da comercialização para o mercado institucional. Na região Central, $45 \%$ da produção é destinada para o autoconsumo, $27 \%$ para o PAA e $20 \%$ para a Merenda, totalizando $47 \%$ para o mercado institucional. Outros $6 \%$ para a venda direta (feiras, quitandas, supermercados), $1 \%$ para troca entre os assentados e 1\% apenas para atravessadores.

Na horticultura, apesar de sua importância para o autoconsumo e abastecimentos dos municípios, os acessos a financiamentos também são poucos, como os demais cultivos: $25 \%$ apenas contra $75 \%$ que não usaram nenhum financiamento. Dos financiamentos feitos, 45\% são do PRONAF, 11\% são do INCRA e 44\% de outros. Já na região Leste também notamos a baixa porcentagem de financiamento da horticultura (apenas 14\%), talvez em função da baixa porcentagem de financiamentos, os assentados acabam priorizando um tipo de sistema de produção e manejo com baixos custos de produção e uma certa autonomia em relação ao uso de insumos externos. Normalmente o produtor procura algum tipo de financiamento para implementação de hortas coletivas ou sistemas automatizados de irrigação.

Um dado interessante extraído da pesquisa foi com relação à preferência de comercialização. Os assentados de ambas as regiões examinadas no presente artigo consideram a horticultura como a melhor opção de comercialização, pois possui inserção em todos os mercados que eles participam, ocupa mão de obra e dá retorno financeiro de forma permanente. Os desafios ficam por conta do financiamento, da assistência técnica e, principalmente, do acesso à água. 
Podemos citar como exemplo o PDS Fazenda da Barra, em Ribeirão Preto. O sistema produtivo predominante é a horticultura, praticamente todos os entrevistados relataram que é a melhor opção para o assentamento, devido ao tamanho de cada lote (1,4 ha) e a proximidade com a cidade de Ribeirão Preto, o que facilita o escoamento da produção, tanto via CONAB, como feiras livres e venda direta. Porém, o assentamento apresenta sério problema com relação à falta de água. A grande maioria dos assentados não possui água nem para consumo doméstico e depende de ligações clandestinas com o bairro vizinho ou da boa vontade da prefeitura de fornecer, via caminhão pipa, água para consumo humano. Percebemos a diferença que há entre lotes próximos a rios e corpos d'água e os distantes, quanto ao aspecto da produção. Outro aspecto é que os assentados reclamam que existem poços já perfurados pelo INCRA e estão sem funcionamento por falta de energia e rede de distribuição. Sem água para irrigar as hortas, a maioria dos lotes ainda apresenta baixa produtividade.

\section{Fruticultura: a fértil expressão da diversificação}

Outra categoria de alimento bastante explorada nos assentamentos das duas regiões é a fruticultura. Além das plantações para autoconsumo e venda da produção em suas diferentes formas, as famílias plantam pés de fruta em volta das casas para o sombreamento e controle da temperatura, num lugar do lote mais conhecido por quintal doméstico.

$\mathrm{Na}$ região Leste, $43 \%$ do cultivo de frutas estão produtivos, $29 \%$ estão produtivos e em implementação e $28 \%$ em implementação. A fruticultura geralmente leva um período maior para florescer e produzir os frutos, quando comparado com a horticultura, cultivo de cereais e de mandioca e outros tubérculos, por este motivo a implementação aparece com porcentagem alta. Os assentados estão sempre plantando árvores frutíferas no entorno da casa e dentro do lote. Na região Central, dos assentados que produzem frutas, $72 \%$ estão em estágio produtivo. Outros $10 \%$ estão implementando pomares em seus lotes. Há também aqueles que já possuem uma área plantada e estão expandindo, representando $18 \%$.

A maior parte desta produção é para o autoconsumo das famílias, sendo responsável por $42 \%$ na região Central. O autoconsumo implica também no consumo de sucos, doces e compotas (além de produtos como bolos e pães, cujas frutas são ingredientes). Para o mercado institucional são destinados $30 \%$ da produção de frutas, 
somando-se os percentuais do PAA e do PNAE. Como disse um assentado da Fazenda da Barra: "O PAA é bom porque você pode vender as coisas que dão no quintal". É justamente o caso da venda de frutas que são plantadas nos quintais domésticos, diversificadas e sem grande escala produtiva.

As vendas diretas e por atravessadores também atingem percentuais significativos, com 10\% e 9\%, respectivamente. Já as trocas são importantes porque não representam um retorno monetário, mas se inserem numa rede de sociabilidade dos assentamentos e possibilitam o acesso aos alimentos com maior abundância dentre as famílias.

Com relação ao destino da produção na região Leste, notamos uma semelhança com a região Central, principalmente pela importância do cultivo para a subsistência e para a comercialização nos mercados institucionais. 36\% dos assentados produzem frutas para o autoconsumo, 32\% para o PAA, e 7\% para merenda escolar. A venda direta é responsável por $19 \%$ do destino da produção, feita para quitandas, supermercados, etc. A comercialização em feiras livres corresponde a $6 \%$.

Novamente notamos a baixa porcentagem de culturas frutíferas financiadas, apenas $8 \%$ dos assentados responderam que houve financiamento, contra $92 \%$ que não recorreram a nenhum tipo de financiamento para iniciar seus pomares. Os poucos financiamentos feitos para o cultivo de frutíferas foram feitos via INCRA.

Explorando a questão do financiamento da fruticultura na região Central, a pesquisa mostra que a maior parte dos pomares foram formados a partir do investimento das próprias famílias, sem financiamento de nenhuma fonte. Apenas 15\% obtiveram financiamento e, dentre essas, as principais fontes foram: Pronaf (37\%), INCRA (25\%) e outros (bancos, financiadoras, etc.) representando 38\%. No entanto, a finalidade de comercialização prepondera, por exemplo, entre aqueles que fizeram uso de financiamento para plantar (isoladamente) banana, manga, abacaxi, maracujá, mamão ou citros, a partir de projetos técnicos de maior produtividade e diferentes, portanto, daquela fruticultura presente nos quintais domésticos.

\section{Tubérculos: as raízes da terra}

A categoria referente à mandioca e outros tubérculos (como o cará, o inhame, a batata inglesa e a batata-doce) também se encontra entre as principais produções das duas regiões, serve de matéria-prima para diversos alimentos, como a própria farinha (principal produto beneficiado a partir da mandioca), o consumo in natura também 
possui um papel extremamente relevante dentro dos projetos de assentamentos pesquisados.

Sobre a região Leste é possível constatar a grande importância das raízes para alimentação e renda das famílias assentadas. Dos assentados que produzem os tubérculos, $80 \%$ das plantações se encontram em estágio produtivo e $20 \%$ em implementação. Da parcela de produtores da região, 43\% produzem para o consumo próprio da família no lote, 33\% para o PAA, 14\% para venda direta ao consumidor e empatados com 5\% para troca e feiras. Este dado reforça a flexibilidade de comercialização da produção, mostrando os diferentes canais possíveis para venda e o balanço com o autoconsumo. Além disso, também há casos de famílias que beneficiam de forma caseira, consomem e comercializam a farinha de mandioca e outros subprodutos.

Na região Central, $88 \%$ dos produtores de tubérculos estão no estágio produtivo, 9\% em implantação e $3 \%$ produzindo e implementando. As raízes servem prioritariamente para o autoconsumo $(43 \%$ dos entrevistados que produzem responderam que cultivam apenas para subsistência), embora exista a possibilidade de venda direta para farinheiras. Muitos assentados almejam uma farinheira industrial nos assentamentos para processarem suas produções e comercializarem com maior valor agregado, porém existem vários entraves para isso ${ }^{11}$.

O mercado institucional responde a $42 \%$ das formas de comercialização de tubérculos, sendo o Programa de Aquisição de Alimentos (PAA) o destino de $28 \%$ da produção, somado a $14 \%$ da merenda escolar. A tendência observada até aqui nos cultivos vegetais, em geral, indica a maior parte destinada ao autoconsumo, seguida pela venda institucional (neste caso, já corresponde a quase metade da produção de raízes). Talvez com o aumento da cota por família/ano no PAA e no PNAE, para o ano de 2012, essa relação favoreça a venda institucional, de maneira a inverter o destino da produção, tornando prioridade a comercialização e consumo do excedente. Vale lembrar que as formas de comercialização não são engessadas, ou seja, os assentados podem realizar vendas não previstas para vizinhos, atravessadores, podem consumir o que pretendiam vender e vice-versa.

\footnotetext{
${ }^{11}$ Em Araraquara, por exemplo, uma farinheira está há vários anos para ser concluída, em parceria com a FERAESP, mas enfrentou problemas e com isso os assentados têm que vender a produção in natura por venda direta ou por meio de atravessadores, para farinheiras de fora do assentamento.
} 
Pela facilidade de propagação das plantas que se enquadram nesta categoria, e o grande número de lotes que possuem pelo menos para autoconsumo, o financiamento deste tipo de cultura é baixo. Na região Leste, apenas $10 \%$ dos produtores tiveram financiamento de suas plantações, sendo o INCRA a única fonte de financiamento encontrada. Na região Central, este dado é bastante semelhante, sendo que apenas $12 \%$ obtiveram financiamento, porém, dos que acessaram, 75\% foram via PRONAF e $25 \%$ via INCRA.

\section{CRIAÇÕES ANIMAIS: poupanças vivas (entre o gosto e o ganho)}

Com relação ao sistema de criação animal dos assentamentos da região Leste, a produção de leite e a criação de pequenos animais como aves e suínos merecem destaque. Os dados apontam que $26 \%$ de toda produção animal são referentes à criação de bovinos leiteiros, $23 \%$ à criação de aves e $13 \%$ à criação de suínos. Outros $23 \%$ se referem aqueles que não possuem nenhum tipo de criação animal em seus lotes. A produção de mel corresponde a $6 \%$, seguido de bovinos de corte e eqüinos, cada um responde a $3 \%$ das criações encontradas.

Nos assentamentos da região Central, podemos perceber uma semelhança com a região Leste com relação às três criações animais mais encontradas. A diferença é que quase $60 \%$ de toda produção animal dos assentamentos da região são referentes à criação de aves e suínos, $37 \%$ e $25 \%$ respectivamente, enquanto que a produção de leite aparece apenas em terceiro lugar, em 16\% dos casos. Com menor destaque aparecem as criações de equinos com $4 \%$, seguido da criação de bovinos de corte com $3 \%$, abelhas com $2 \%$. Apenas $9 \%$ não possuem nenhum tipo de criação animal em seus lotes. Ainda aparece caprino-ovinos e a piscicultura com $1 \%$ cada e outras criações com $2 \%$, que no caso são coelhos e patos.

Porém, quando falamos em criação animal nos assentamentos, novamente não podemos encarar como um modelo engessado. A flexibilidade do processo é grande, de forma que os assentados podem trabalhar na perspectiva da criação para o consumo da família, mas, dependendo de sua situação financeira, do preço no mercado, do número de animais e mão de obra, acabam realizando a comercialização.

\section{Gado Leiteiro}

Explorando a questão da pecuária leiteira na região Central, a pesquisa mostrou que, dentre aqueles que possuem algum tipo de criação animal em seus lotes, 28\% 
trabalham com leite. Em destaque para este tipo de criação podemos citar os assentamentos de Colômbia e Iaras. Já no Projeto de Desenvolvimento Sustentável (PDS) Fazenda da Barra, em Ribeirão Preto, que representou grande parte da amostragem, segundo um dos assentados, não é permitido criar animais de grande porte, pois o assentamento está inserido em uma área de recarga do Aqüífero Guarani. Após diversas discussões sobre o assunto, isso foi oficializado no Termo de Ajustamento de Conduta (TAC) nesse assentamento. Outro fator que contribui é o tamanho do lote, conforme já mencionado, que limita os assentados às criações de pequeno porte, embora tenhamos constatado que daí surge iniciativas de diversificação desse tipo de criação (coelhos, patos, caprinos etc.).

$\mathrm{Na}$ região Leste, esta porcentagem é ainda maior, representando $38 \%$ dos entrevistados que trabalham com a produção de leite. Ou seja, a pecuária leiteira é responsável por contemplar o maior número de lotes que trabalham com algum tipo de produção animal na região. O sistema de produção de leite predominante pode ser comparado com o sistema de produção dos bovinos de corte. A alimentação baseada no modelo extensivo de exploração, com pastagens nativas, ou gramíneas introduzidas pelos antigos latifundiários, geralmente do gênero brachiaria, porém sem nenhum tipo de manejo para melhorar a qualidade do volumoso. Normalmente estas pastagens apresentam algum grau de degradação, para suprir as necessidades do animal os assentados gastam muito dinheiro com rações comerciais, onerando os custos de produção e inviabilizando a atividade. A ordenha é feita manualmente, com pouca ou nenhuma preocupação com a higiene e com a contaminação do leite. De maneira geral, os animais são cruzados, prevalecendo às raças zebuínas, que são mais adaptadas ao clima, mas tendem a ter uma menor produção em relação às raças européias. É comum observar animais de dupla aptidão, ou seja, raças específicas para produção de leite cruzadas com animais de raças voltadas para produção de carne (principalmente a raça nelore). Nesta perspectiva, se os bezerros nascem machos, são mantidos no lote para posteriormente serem vendidos como gado de corte e, se nascem fêmeas, ficam no lote como futuras matrizes e produtoras de leite. Porém, deve-se tomar cuidado e observar o que é mais rentável em cada caso, pois é comum nascerem fêmeas cruzadas com produção de leite abaixo do esperado e machos com ganhos de peso inferiores ao ideal para um bom retorno financeiro. 


\section{Novas tecnologias entram em cena}

Existem diversos exemplos de assentados que estão sempre buscando se atualizar e aderir às novas tecnologias ${ }^{12}$. Muitos assentados sabem fazer um manejo adequado e aplicam técnicas ecológicas de produção de leite, a utilização de plantas para o controle de endo e ectoparasitas é um exemplo. Como é o caso do Nim (Azadiracta indica), uma árvore de crescimento rápido, suas folhas são usadas para o controle de ectoparasitas como carrapatos, bernes, etc. As folhas da goiabeira, jabuticabeira, são fervidas e ministradas via oral para controle de diarréia nos bezerros, a babosa é muito utilizada para tratamento de mastite e muitos outros manejos interessantes de serem propagados. Como exemplo, podemos citar o caso do Projeto de Assentamento 23 de Maio em Itapetininga. Por meio da Secretaria de Agricultura e Meio Ambiente, a Prefeitura de Itapetininga firmou convênio com o Ministério de Minas e Energia (MME) para a implantação do Programa de Fortalecimento das Pequenas Propriedades Rurais- Leite. De acordo com a administração municipal, o projeto prevê a capacitação e acompanhamento técnico dos pequenos produtores, implantação de pastejo rotacionado, aquisição de tanques de resfriamento comunitário, tanque rodoviário para transporte de leite, além de insumos que dão suporte à produção de leite de forma sustentável. O projeto tem o objetivo de auxiliar os pequenos produtores na hora de produzir, armazenar e comercializar os produtos, permitindo aumentar o ganho dos produtores e atender às expectativas dos envolvidos na cadeia de produção de leite local.

Através dos dados da pesquisa foi possível traçar o perfil do foco da produção de leite desta região. Dos lotes entrevistados que trabalham com a atividade leiteira, $89 \%$ produzem o leite apenas para autoconsumo e $11 \%$ realizam algum tipo de comercialização. Ou seja, o leite produzido serve primeiramente para consumo próprio da família no lote e o excedente é levado aos tanques comunitários para ser resfriado e vendido para empresas da região. É possível perceber que apenas 5\% dos entrevistados que produzem leite realizam venda de forma ocasional e 95\% não se aplica, ou seja, produzem apenas para autoconsumo da família no lote. Os contratos formais com laticínios são pouco comuns, sendo mais característica a venda ocasional dentro do próprio assentamento ou na cidade de maneira informal. Outra forma de

\footnotetext{
${ }^{12}$ Novas tecnologias não necessariamente precisam ser instalações caras, gastos excessivos de dinheiro com estruturação do sistema produtivo, etc. Manejos simples e de baixo custo impulsionam a pecuária leiteira na agricultura familiar e permitem um retorno financeiro adequado.
} 
comercialização é através dos subprodutos do leite. Além de agregar valor, diferencia o produto final. Foram observados na pesquisa de campo que os produtos mais encontrados são os queijos e os requeijões, que também são comercializados de maneira informal dentro do assentamento ou em feiras nas cidades próximas.

Uma das maiores conquistas relacionadas à cadeia produtiva do leite dentro dos assentamentos da região é o acondicionamento coletivo do produto em tanques de resfriamento que melhoram o valor recebido por litro e adéquam a produção às novas exigências do Ministério da Agricultura (MAPA). A construção de laticínios dentro do assentamento é o sonho de muitos assentados e realidade no Projeto de Assentamento Pirituba II, na cidade de Itapeva ${ }^{13}$. Na agrovila I existe um laticínio que promove o envase do leite em saquinho e a produção de derivados como os queijos, bebidas lácteas, iogurtes, doces, etc. A usina do leite é uma conquista dos assentados e capta grande parte do leite produzido em toda região. O produto beneficiado possui marca própria (raízes da terra) e selo de inspeção municipal (SIM) com aval de comercialização da vigilância sanitária.

Explorando a questão do destino da produção referente à bovinocultura leiteira na região Central, é possível afirmar que $50 \%$ do leite retirado do animal serve apenas para autoconsumo da família no lote, $43 \%$ dos entrevistados realizam a venda da produção, 3\% a venda dos animais e 4\% responderam todas as opções. Com isto, podemos dizer que prioritariamente o leite produzido é destinado para o autoconsumo, o excedente da produção normalmente é levado aos tanques de resfriamento do assentamento, para ser comercializado através das associações e cooperativas para os laticínios da região. Este formato é semelhante ao da região Leste. A venda do animal pode se dar em todos os momentos do processo produtivo, a depender das necessidades da família, já que os animais são vistos como poupanças vivas. Os bezerros machos geralmente são vendidos e destinados para engorda, e quando atingem o ponto de abate, são comercializados para frigoríficos. As vacas mais velhas que já deram mais do que cinco crias tendem a produzir menos leite nas últimas lactações e também são vendidas para atravessadores com destino ao abate.

É importante ressaltar que a pesquisa foi realizada no período seco do ano, fato que pode estar relacionado com a alta incidência da produção apenas para autoconsumo,

\footnotetext{
${ }^{13}$ Embora o assentamento não tenha entrado na amostragem da pesquisa, ele está inserido na região Leste e através do curso de capacitação em Boas Práticas na Bovinocultura Leiteira, realizado no mês de maio/2011 foram feitas diversas observações de campo e conversas informais com os assentados e técnicos da região sobre o sistema produtivo.
} 
pois devido à falta de chuva, as pastagens não produzem a massa verde necessária para suprir as exigências nutricionais dos animais e, com uma dieta abaixo do ideal, a produção cai. Fato observado em praticamente todos os lotes visitados que produzem leite. Há relatos dos assentados, por exemplo, dizendo que na época das chuvas, a produção chega a 50 litros por dia e, na época de seca, cai para 20 litros. A época da pesquisa pode ter influenciado a alta porcentagem relativa apenas para autoconsumo, pois na época das chuvas, o excedente da produção é comercializado, podendo este dado aparecer camuflado. Isso revela, mais uma vez, como o cálculo entre consumo e comercialização muda em diferentes épocas do ano em função do clima.

Referente ao tipo de comercialização, constatou-se que 54\% dos assentados realizam a venda ocasional. Este dado vem de encontro com o descrito acima e mostra que se houver excedente da produção, este ocasionalmente pode ser vendido e, assim, $38 \%$ comercializam o leite de maneira formal, com contrato/empresa - normalmente o leite produzido é levado até os tanques de resfriamento comunitários dentro do assentamento e vendidos para os laticínios da região a partir de contratos de fornecimento entre as cooperativas/associações e empresas - e $8 \%$ vendem para atravessadores. Geralmente a figura do atravessador aparece quando o assentamento não possui tanque de resfriamento, como é o caso do assentamento Bela Vista do Chibarro, em Araraquara. Os assentados produtores de leite ficam necessariamente atrelados aos atravessadores que possuem tanque de resfriamento e acabam recebendo até 15 (quinze) centavos a menos pelo litro.

O tanque de resfriamento pode representar uma conquista para muitos assentados da região, pois o equipamento ajuda a manter a qualidade do produto, adequando-se ao padrão de qualidade exigido pelo Ministério da Agricultura e facilita a comercialização para os laticínios da região sem precisar passar pela mão dos atravessadores. No campo das possibilidades, pode ainda despertar interesse das famílias em trabalhar em grupo, porque além de gerar renda, promove a inclusão no processo produtivo local.

Como exemplo, podemos citar o caso do assentamento Zumbi dos Palmares, em Iaras, que possui três tanques de resfriamento, cada um agrega em média 12 produtores. Com capacidade para mil litros, chega a receber 300 litros por dia, o caminhão do laticínio passa em dias alternados, levando cerca de 600-700 litros. O leite resfriado não estraga e o produtor dificilmente perde sua produção como é comum acontecer sem o resfriamento rápido e adequado do produto. Ainda com relação ao Assentamento Zumbi 
dos Palmares, através da pesquisa de campo pudemos perceber o grande número de famílias que beneficiam o leite em seus subprodutos, com intenção principalmente de agregar valor e vender com mais facilidade o produto. Exemplos como de uma senhora que é referência na produção de doces, principalmente de leite, abóbora e bolachas e têm seus produtos bastante procurados pelos assentados. Outro caso relatado foi de um dos entrevistados que produzia requeijão e vendia toda produção dentro do próprio assentamento, porém segundo ele promovia a venda fiado aos vizinhos e muitas vezes nunca recebia. Por este motivo, resolveu parar de beneficiar o leite e começou entregar no tanque de resfriamento comunitário do assentamento.

Sobre o financiamento para iniciar a atividade leiteira na região Leste, concluímos que $71 \%$ acessaram os recursos do PRONAF para compra dos animais e $29 \%$ utilizaram recurso próprio. Já na região Central, para aquisição dos animais, 56\% dos entrevistados recorreram ao financiamento via PRONAF e 44\% utilizaram recurso próprio. Através destes dados podemos traçar um paralelo entre as duas regiões e concluir que, com relação à utilização dos recursos para o sistema de produção animal, a bovinocultura leiteira é a criação que os assentados mais utilizam financiamento para iniciar a atividade.

\section{Aves: o sabor da produção caipira}

$\mathrm{Na}$ região Leste, dos assentados que responderam os questionários, 33\% possuem em seus lotes criação de aves e $67 \%$ dos assentados não possuem. Dos assentados que possuem criação de aves em seus lotes, 55\% têm como foco principal a produção de ovos e $45 \%$ trabalham na perspectiva dos animais para corte.

O destino da produção da avicultura nos assentamentos pesquisados da região Leste foi assim distribuído: 50\% para o autoconsumo, 12\% para venda animal, 13\% a venda da produção de ovos e $25 \%$ referente a todas as opções. Os ovos prioritariamente são para consumo da família e o excedente é voltado para comercialização ocasional. As aves para corte seguem a mesma linha de raciocínio: são destinadas para autoconsumo, porém se houver demanda são comercializadas. $75 \%$ dos animais que são comercializados o são de forma ocasional e $25 \%$ são vendidos para atravessadores locais. Não foram encontradas vendas formais, referentes às aves de corte e de postura, mostrando que o sistema de integração entre os frigoríficos e produtores não são comuns nos projetos de assentamentos da região Leste. 
Já na região Central pôde-se constatar o inverso: $68 \%$ dos entrevistados possuem criação de aves e 32\% não. Na região Central, $64 \%$ das aves são criadas para venda e/ou consumo da carne (corte) e $36 \%$ têm como foco o consumo e/ou comercialização de ovos (postura). Na prática, estes dados se cruzam, pois o principal modelo de criação dos assentamentos é baseado principalmente na subsistência e no sistema pouco intensivo em capital, sendo que para esta finalidade interessam animais chamados de dupla aptidão, ou seja, as galinhas precisam ser capazes de produzir ninhadas, cujos frangos machos possam ser abatidos aos seis meses de idade e as fêmeas integrem o plantel de produção de ovos. Por outro lado, as galinhas destinadas à postura, quando se tornam velhas são abatidas para consumo próprio da família, ou são comercializadas de maneira informal dentro do próprio assentamento ou vendidas nas cidades próximas. As raças mais comuns observadas nos projetos de assentamentos da região Central foram: Plymouth Rock Barrada (carijós), Rhode Island Red (vermelhas) e New Hampshire. A correta escolha da raça das galinhas para criações de subsistência e para criações comerciais é imprescindível para evitar surpresas desagradáveis no futuro.

O destino da produção na região Central é marcado pela importância da criação destinada para consumo familiar, pois $52 \%$ dos assentados que possuem criação de aves produzem para autoconsumo, 35\% realizam a venda animal, 10\% vendem a produção de ovos e 3\% trabalham com todas as opções.

O tipo de venda está relacionado com os dados descritos acima, com $67 \%$ da produção destinada para venda ocasional e $27 \%$ considerado não se aplica, que no caso são os produtores que não realizam a comercialização. Podemos dizer que a maioria da produção é prioritariamente para subsistência da família no lote e, ocasionalmente, as aves e a produção de ovos podem ser comercializadas. Apenas 3\% dos assentados que realizam a comercialização o fazem para atravessadores. Há outros $3 \%$ que possuem contratos de integração junto a empresas do setor avícola.

Com relação ao sistema produtivo, podemos traçar um paralelo entre as duas regiões, pois através da pesquisa de campo foi possível constatar a grande heterogeneidade do sistema. De maneira geral, a produção de galinha caipira solta nos quintais foi o mais encontrado. Este modelo tem como característica principal ser o mais econômico e usado na agricultura familiar, sem se preocupar apenas com o retorno financeiro e sim produzir um alimento de qualidade com o máximo respeito ao animal, pois são livres para explorar toda área onde vivem, comem tudo que encontram na 
natureza (limpam o terreno) e também são alimentados com sobras de comida e da produção.

Já no sistema de integração por meio dos contratos junto a empresas, a indústria integradora, além de fornecer a ração, arca com os custos da assistência técnica, fornece e transporta os pintos de um dia, fornece medicamentos e transporta as aves adultas da granja ao abatedouro. Ao produtor integrado cabem os custos da construção do galpão e da aquisição dos equipamentos, da mão de obra para o manejo, da energia para iluminação, aquecimento e ventilação do aviário e da aquisição da "cama" para forrar o piso dos aviários. E necessariamente precisam entregar os frangos terminados para as empresas integradoras. Os assentados que aderem a este modelo produtivo não podem ter outras aves caipiras por causa do risco de contaminação das aves da granja industrial. Em trabalho de campo exploratório sobre essa parceria, detectamos o alto custo da montagem deste tipo de granja (que chega a R\$ 100 mil) e para a manutenção do sistema (com energia e ração, por exemplo), enquanto que o contrato não previa a obrigatoriedade da empresa em manter a granja produzindo o ano todo.

Com relação à origem dos recursos utilizados para iniciar a criação de aves, os dados mostram que a grande maioria na região Central $(77 \%)$ não recorreu a nenhum tipo de financiamento, $10 \%$ obtiveram recurso do INCRA e $8 \%$ utilizaram financiamento do PRONAF para iniciar suas criações. Ainda aparecem com $2 \%$ outras fontes de financiamento, geralmente adquiridos através de bancos. Os assentados integrados às empresas geralmente são aqueles que dispunham de imóveis fora do assentamento e os vendem para montar a granja. Os dados da região Leste são semelhantes, embora existam bem menos produtores avícolas, já que $67 \%$ da origem dos recursos empregados para aquisição das aves são próprios, sem a obtenção de financiamento, $16 \%$ obtiveram financiamento do INCRA e $17 \%$ utilizaram o PRONAF para aquisição dos animais.

\section{Suínos: as dificuldades da comercialização ocasional}

$\mathrm{Na}$ região Leste, a suinocultura está presente em $24 \%$ dos lotes dos assentamentos pesquisados. As instalações para criação são das mais variadas possíveis, foram observados sistemas de produção ao ar livre, normalmente criados em piquetes com estruturas cobertas para se alojarem, até pequenos confinamentos. 
Os materiais utilizados para construção são bem diversificados, alguns chiqueiros construídos de madeira com as sobras do antigo barraco que o assentado morava e cobertos com telha de Eternit, até baias construídas de alvenaria e cobertas com telhas. Um entrave observado foi com relação à instalação da maternidade. As matrizes criadas ao ar livre e mesmo as criadas nas baias sem proteção lateral não percebem a presença dos leitões que estão próximos querendo mamar e acabam deitando em cima deles, causando sua morte por esmagamento, uma das principais causas de morte na fase que os animais são recém-nascidos. O manejo de aplicar ferro quando o leitão nasce é de suma importância e praticamente todas as criações visitadas na região realizam esta prática. A dieta principal dos animais é baseada na lavagem, porém sem nenhum balanceamento específico para as diferentes categorias. As lavagens observadas foram feitas dos mais diferentes alimentos e preparadas de diferentes formas. Desde sobras da alimentação da família, como arroz, feijão e vegetais preparados para consumo humano, até alimentos preparados exclusivamente para os suínos, como misturas de milho e feijão cozidos. Alguns assentados complementam a alimentação com espigas de milho in natura, forrageiras picadas e perdas dos legumes e vegetais das hortas.

Com respeito à destinação da produção na região Leste, constatou-se que $83 \%$ dos entrevistados que possuem este tipo de produção animal produzem para autoconsumo e apenas $17 \%$ comercializam os animais. Esta comercialização aparece como $100 \%$ de forma ocasional. Ou seja, os produtores num primeiro momento criam os suínos para consumo da família no lote. E caso houver interessados em comprar os leitões, os animais em fase de criação ou mesmo terminação (prontos para abate) e a oferta for interessante, eles acabam vendendo. Alguns destes assentados fazem planejamento e seguram os animais no lote para que estejam na época de abate próximo do Natal, esta época se apresenta como um nicho de mercado interessante e é bastante explorado pelos assentados.

Abordando um exemplo de estratégia de comercialização tanto dos suínos como de galinhas caipiras podemos citar o caso do PDS São Luiz, em Cajamar/SP. Isto porque o assentamento fica bem no meio de um conjunto de chácaras utilizadas para lazer nos finais de semana, por pessoas das cidades próximas. Para se ter acesso às chácaras, obrigatoriamente as pessoas precisam passar pela estrada que corta o assentamento, daí a estratégia de colocar diversas placas de anúncio de venda de galinha caipira, porco caipira e hortaliças na entrada dos lotes, ficando visível para quem passa. 
Segundo relato dos assentados, nos finais de semana, o movimento na estrada é intenso, e a procura pelos produtos é grande. Esta é uma das principais formas de comercialização da produção de pequenos animais nesse assentamento.

$\mathrm{Na}$ região Central, a suinocultura está presente em $43 \%$ dos lotes. Isto ressalta a importância desta categoria animal para o fortalecimento da agricultura familiar nos assentamentos desta região. A suinocultura é muito importante tanto para completar a renda familiar, como para fornecer proteína animal na alimentação das famílias. Sendo que $58 \%$ dos assentados que trabalham com esta categoria animal realizam a comercialização e $42 \%$ produzem para autoconsumo. Daquele que comercializam a produção, 54\% disseram realizar a venda do animal, sem nenhum tipo de beneficiamento e $4 \%$ vendem a produção processada. Neste último caso, normalmente, os assentados abatem os suínos no próprio lote e comercializam os cortes prontos ou fazem linguiça, de modo que conseguem agregar maior valor ao produto final, mas o número baixo indica a precariedade de acesso a um selo de inspeção que permita sua comercialização.

Dos assentados que realizam a comercialização tanto dos animais quanto da carne beneficiada, quase todos (95\%) vendem de maneira ocasional, e apenas 5\% para atravessadores. Através deste dado podemos concluir que o foco da criação é sempre para subsistência da família no lote, os assentados produzem para autoconsumo e ocasionalmente promovem a venda na comunidade, dependendo de vários fatores como: número de animais, situação financeira da família, etc.

Através dos dados qualitativos da pesquisa podemos notar o grande potencial de comercialização tanto de aves, como de suínos da região Central. A maioria dos assentados que trabalham com algum tipo de produção animal veem nos pequenos animais os produtos de melhor valor agregado e melhor rentabilidade para se trabalhar dentro do lote.

Para iniciar a criação de suínos, na região Leste, 29\% dos entrevistados utilizaram o Pronaf como financiamento e $71 \%$ usaram recursos próprios. Na região Central uma realidade parecida, na qual $80 \%$ dos entrevistados que trabalham com esta atividade utilizaram recurso próprio para aquisição dos animais e estruturação das instalações e apenas $4 \%$ dos assentados recorreram a recursos do Pronaf, do INCRA ou buscaram financiamento via banco. 
Vale a consideração de que o financiamento de criações animais, quando feito nas duas regiões, a maioria usa para compra de bovinos leiteiros. Para iniciar a criação de pequenos animais (aves e suínos), a maioria não busca financiamento e sim investe recurso próprio.

Com menor representatividade apareceram outros tipos de produção de alimentos e/ou produtos de origem animal, como o mel, bastante explorado nos assentamentos considerados PDS, os ovinos e caprinos, equinos (estes, principalmente utilizados para trabalhos dentro do lote e transporte), também foram observadas criações de coelhos e patos.

\section{A título de conclusão ou as marcas principais do retrato do sistema produtivo}

Apesar de não aprofundar na trama dos agentes envolvidos nas perspectivas e bloqueios ao desenvolvimento dos assentamentos, o artigo oferece um retrato das possibilidades e alternativas de outro modelo de desenvolvimento para além da integração agroindustrial. Como vimos nos dados apresentados, o sistema produtivo dos assentamentos das duas regiões envolve, predominantemente, o cultivo de cereais, hortaliças, frutas e tubérculos, criações de gado leiteiro, aves e suínos, mas isso acontece das mais variadas formas. Tais sistemas dependem de toda uma infraestrutura, acesso à água, insumos, informação, créditos, mercados, o número de pessoas na família, dentre muitos outros fatores que não foram explorados no presente artigo. Procuramos fazer aqui um retrato que expressasse algumas marcas dos sistemas produtivos e da comercialização da produção nos assentamentos.

Considerados esses cultivos vegetais e animais, vimos que a parte destinada ao autoconsumo é alta em todos eles e, com relação aos cultivos vegetais, que se trata de uma produção que além de consumida pelas próprias famílias é em grande medida comercializada em programas institucionais e feiras, além de se inserirem numa rede de trocas de alimentos no interior dos assentamentos. As criações animais ainda estão em um patamar de comercialização ocasional. Consideramos ainda que todos eles são alimentos enraizados na dieta da população. O milho e as raízes, por exemplo, têm maior durabilidade sem serem colhidos, por isso podem ser aproveitados de diversas maneiras no interior do lote e nas formas de comercialização, o que aumenta a variabilidade da destinação desses produtos e os tornam estratégicos para as famílias assentadas. 
Neste sentido, vale destacar a diversidade nas formas de comercialização, igualmente estratégicas, como as feiras e venda direta que já existiam na maior parte dos casos e, mais recentemente, o mercado institucional. Trata-se de significativos meios de comercialização que vão sendo constituídos nos municípios do entorno e implicam na construção de relações entre a cidade e o campo. No caso dos assentamentos antigos, é um mercado historicamente constituído, já que vários assentados começaram a comercializar os produtos de carrinho de porta em porta, aos poucos foram adquirindo seus veículos e estabelecendo relações com quitandas, supermercados e restaurantes. Por outro lado, são relações constituídas com os consumidores que frequentam feiras e compram direto do produtor e contribuem para formar a representação social das pessoas que vivem nas cidades sobre os assentados e vice-versa. São importantes canais de comercialização para que os assentados não dependam de atravessadores, nem de grandes volumes para entregar, como acontece nas parcerias industriais e com beneficiadoras.

Além da relação junto à população local, a boa relação com algumas prefeituras tem permitido significativos avanços no desenvolvimento local a partir da criação do mercado institucional de alimentos (via PAA e PNAE). Por outro lado, existem assentados que reclamam da falta de informação qualificada sobre o PAA em seus municípios e há atrasos de pagamento consideráveis. Fica claro, a partir dos dados, que a falta de selos de inspeção municipais impede que as produções de ovos, de carne de frango e de porco cheguem às cidades de forma regular. Apesar disso, atualmente esses programas já correspondem à principal parcela dos rendimentos das famílias assentadas.

Existem grandes expectativas de aumentar o valor agregado da produção, por meio da agroindustrialização caseira/comunitária como meios de se intensificar a ocupação de mão de obra familiar nas atividades produtivas. O mercado institucional vem abrindo perspectivas para isso, mas na maioria dos casos é a prefeitura que beneficia a produção antes dela ser distribuída às escolas e demais instituições atendidas, e não os próprios produtores. Tal aspecto não deixa de ser revelador da falta de linhas de créditos, capacitação e assistência técnica na área da agroindustrialização.

O retrato construído nos deixa uma série de questões. O PAA e o PNAE vêm se consolidando como perspectivas para a inversão do cálculo familiar (consumo/comercialização)? Na medida em que os principais produtos comercializados são itens que compõem o cardápio cotidiano das famílias e muitas vezes advindos do 
quintal doméstico, como fica agora a valorização da produção que antes era adstrita ao autoconsumo e o papel das mulheres (principais protagonistas nessa produção)? Os homens passam a controlar a organização da produção e da comercialização dessa produção porque passam a gerar parcela significativa da renda familiar? Será que a abertura dos mercados institucionais são possibilidades de potenciar a função social dos assentamentos para os municípios nas regiões onde estão inseridos e assim aumentar, qualitativamente, as relações campo-cidade? Questões a exigir o continuado acompanhamento de tais programas e das condições que perpassam a produção e a reprodução social dos assentados.

\section{REFERÊNCIAS}

BOURDIEU, P. O Poder Simbólico. Rio de Janeiro: Difel, 1989.

DUVAL, H.C. Da Terra ao Prato: um estudo das práticas de autoconsumo em um assentamento rural. 2009. Dissertação (Mestrado em Agroecologia e Desenvolvimento Rural). Universidade Federal de São Carlos, Araras, 2009.

FERRANTE, V.L.S.B. et al. Assentamentos rurais: um olhar sobre o difícil caminho de constituição de um novo modo de vida. Retratos de Assentamentos, Araraquara, n.1, Nupedor/Unesp, p.75-148, 1994.

FERRANTE, V.L.S.B. Assentamentos Rurais $\mathbf{x}$ Desenvolvimento: integração, diversificações, contrapontos e complementaridades. Projeto de Pesquisa Bolsa Produtividade CNPq (2010-2015), 2010.

FERRANTE, V.L.S.B.; BARONE, L.A. Parcerias com a cana-de-açúcar: tensões e contradições no desenvolvimento das experiências de assentamentos rurais em São Paulo. Sociologias (Versão Impressa), v.13, UFRGS, p.262-305, 2011.

FERRANTE, V.L.S.B.; ALY JR, O. (Coords.) Relatório de Pesquisa. Relatório final de pesquisa sobre diagnósticos regionais dos assentamentos, análise de sua inserção na economia local e da recepção, implementação e execução das políticas públicas realizadas pelo INCRA-SP. Contrato/CRT/SP/N. 100000/2010 - INCRA/UNIARA, 2011.

GARCIA Jr., A.R. Terra de Trabalho. Trabalho familiar de pequenos produtores. Rio de Janeiro: Paz e Terra, 1983.

INCRA-SP. Retratos do Campo. A reforma agrária que produz e alimenta. Ano 1, v.1, 2010.

SEN, A. Desenvolvimento como liberdade. São Paulo: Cia. das Letras, 2000. 